\title{
Effects of Dust on Radiation Transfer in the Martian Atmosphere (I)
}

\author{
- On Infrared Radiative Cooling -
}

\author{
By Shigeru Moriyama \\ The Physical Science Laboratories, Nihon University at Narashino, Funabashi, Chiba, Japan \\ (Manuscript received 28 February 1974, in revised form 15 October 1974)
}

\begin{abstract}
The equations of infrared radiation transfer are numerically solved for the Martian atmosphere, with consideration of the effect of dust, which absorbs, emits and scatters light. Primary mineral constituent of dust, we assumed, is quartz. Three cases on dust concentration are considered: the first corresponds to a heavy dust storm event, the second to a dusty case and the third to out-of-storm case. From the solutions obtained by the method of an iterative numerical integration, radiative heating or cooling rates in the atmosphere are calculated as a function of height.

The computation results show that on Mars, the infrared radiative cooling rates due to dust cannot be overlooked in the lower levels within dusty atmosphere. Especially, at a dust storm event, cooling in the infrared regions would be a very important term as well as heating due to absorption of the incident solar radiation by dust, and the thermal structure of the Martian atmosphere seems to be determined by dust alone. Our result also indicates that even at out-ofstorm events, cooling rate due to dust seems to have the same order as the magnitude of infrared radiative cooling due to $\mathrm{CO}_{2}$.
\end{abstract}

\section{Introduction}

Dust particles, which are blown up by wind and suspended in the planetary atmosphere, would be effective in transfer problem for the incoming solar radiation and also for outgoing infrared (IR) planetary radiation. In the case of the Martian atmosphere, we have some evidences showing the existence of the heavy dust layer: broad diffuse absorption feature in IR region by Mariner 9 IR spectroscopy experiment (Hanel et al., 1972), and ocher-colored veiling, frequently reported by ground-based observers, over the entire surface of the planet at the dust storm events for a few months duration. Moreover, when we consider the theoretical results that the time of falling down of the particles from the height of four times of the Martian scale height is about 130 days for $1 \mu \mathrm{m}$ diameter particles and about two years for $0.2 \mu \mathrm{m}$ diameter particles (Gierasch and Goody, 1973), we can expect that the Martian atmosphere would be still contaminated by these small particles, at out-of-storm events.
Previous investigations on thermal structure of the Martian atmosphere have been done on radiative computations for gaseous components alone (e.g., Ohring and Mariano, 1968; Gierasch and Goody, 1968; Moriyama, 1972). However, the observed vertical temperature profiles are closer to isothermal than computed profiles. Average of the values of the excess of the computed temperature from the observed is about $50 \mathrm{~K}$. Gierasch and Goody (1972) argued that the excess of temperature is almost certainly due to direct absorption of solar radiation by dust. They pointed out that absorption of $10 \%$ of the incident solar radiation is requested within the atmosphere, in order that the computed temperature profiles might be in good agreement with the Mariner observations.

However, their discussion is still imperfect, because infrared radiation due to dust in the atmosphere would play some important roles in establishing the thermal structure through emission, absorption and scattering processes in it (Peterson, 1968; Sargent and Beckman, 1973). If 
IR radiative cooling rate due to dust is large enough, we cannot neglect the effect on radiative transfer problem in the Martian atmosphere, and much more amount of solar absorption due to dust would be required in order to explain the observed atmospheric thermal structure. Actually, analyses of Mariner 9 observations indicate that about $20 \%$ of the incident solar radiation is absorbed within the dusty Martian atmosphere and an effective atmospheric emissivity of 0.53 would be required to achieve adequate nighttime cooling (Pirraglia and Conrath, 1974).

The purpose of this study is to estimate the contributions due to dust, with considering the effect on heat budget in the Martian atmosphere, especially in IR region. Our adopted model is pure $\mathrm{CO}_{2}$ atmosphere with some amount of dust particles. The transfer equations for IR radiation are solved numerically, but transfer for incident solar radiation is not considered here. We will discuss it in detail in the next paper.

\section{Basic equations}

The equation of radiative transfer for monochromatic radiation in a plane parallel atmosphere is

$$
\begin{aligned}
\eta \frac{d I_{v}(z, \eta)}{d z}= & -K_{v}(z) I_{\nu}(z, \eta)+A_{\nu}(z) B_{\nu}(T) \\
& +\frac{1}{2} S_{v}(z)\left[\int_{-1}^{1} I_{\nu}\left(z, \eta^{\prime}\right) P_{\nu}\left(\eta, \eta^{\prime}\right) d \eta^{\prime}\right]
\end{aligned}
$$

where $\eta$ is the cosine of the zenith angle, $z$ the vertical distance coordinate, $\nu$ the wavenumber, $I_{\nu}$ the monochromatic radiation intensity. $K_{\nu}, A_{\nu}$ and $S_{v}$ are the monochromatic volume extinction, absorption and scattering coefficients, respectively. $B_{v}$ is the black body emission, $T(z)$ the temperature at $z$, and $P_{v}$ the scattering phase function.

The extinction coefficient can be expressed as the sum of an absorption coefficient and a scattering coefficient:

$$
K_{\nu}=A_{\nu}+S_{\nu} .
$$

The single scattering albedo $\tilde{\omega}_{\nu}$ is

$$
\tilde{\omega}_{\nu}=S_{\nu} / K_{\nu} .
$$

From eqs. (1) to (3), we obtain the following equation:

$$
\begin{aligned}
\gamma_{i} \frac{d I_{\nu}(z, \eta)}{d z}= & -K_{\nu}(z)\left\{I_{\nu}(z, \eta)-\left(1-\tilde{\omega}_{\nu}\right) B_{\nu}(T)\right. \\
& \left.-\frac{\tilde{\omega}_{\nu}}{2} \int_{-1}^{1} I_{\nu}\left(z, \eta^{\prime}\right) P_{\nu}\left(\eta, \eta^{\prime}\right) d \eta^{\prime}\right\} .
\end{aligned}
$$

Monochromatic upward and downward fluxes are

$$
F_{\nu} \uparrow(z)=2 \pi \int_{0}^{1} I_{\nu} \uparrow(z, \eta) \eta d \eta
$$

and $\quad F_{v} \downarrow(z)=2 \pi \int_{0}^{-1} 1_{\nu} \downarrow(z, \eta) \eta d \eta$.

The rate of temperature change in the atmosphere is:

$$
\frac{d T(z)}{d t}=-\frac{1}{\rho(z) C_{p}} \cdot \frac{\partial\{F \uparrow(z)-F \downarrow(z)\}}{\partial z},
$$

where $t$ is time, $\rho(z)$ the density of atmosphere at $z, C_{p}$ the specific heat at constant pressure. $F \uparrow$ and $F \downarrow$ are upward and downward total fluxes integrated over infrared spectral regions.

\section{The numerical model}

We used the Mariner data and assumed that the vertical temperature gradient $\partial T / \partial z$ is -2.2 $\mathrm{K} / \mathrm{km}$ and the temperature at $z=0$ is $240 \mathrm{~K}$, in our model atmosphere.

The coefficients $K_{v}, S_{v}$ and $A_{v}$ of dust are function of the complex index of refraction of the constituent particles. For the common minerals, complex index of refraction depends strongly on wave length, especially in IR region, but except the case of quartz, very little is known on definite values.

According to the discussion by Hanel et al. (1972) on Mariner data, spectral features of the atmospheric dust indicate $\mathrm{SiO}_{2}$ content of $60 \pm 10 \%$.

In this study we assume that quartz is the primary mineral constituent of the dust particle, and adopt the results by Spitzer and Kleinman (1961) and Peterson and Weinman (1969) for the optical parameters of the quartz. We can compute the values of $K_{v}, S_{\nu}$ and $A_{v}$ for quartz particles, using Mie's theory.

The coefficients $K_{v}, S_{v}$ and $A_{v}$ are also function of the size distribution of dust. For example,

$$
K_{\nu}=\pi \int_{r_{1}}^{r_{2}} r^{2} Q_{e x t}(r, \nu) d n(r),
$$


where, $Q_{e x t}$ is called an efficiency factor for extincition, $d n(r)$ is the number of particles per cubic centimeter per micron within the radius interval $d r$. The efficiency factor is a function of three parameters: particle radius, radiation wavelength, and the complex index of refraction of the particles. If these three quantities are known, the determination of the $Q$ 's follows readily. Unfortunately, we have no enough knowledge on the particle size distribution in the Martian atmosphere.

So, we assume, in this study, the following size distribution in all layers:

$$
\begin{aligned}
& d n / d r=13 r^{-3.5} \mathrm{~cm}^{-3} \mu^{-1} \quad(0.1 \leq r \leq 15 \mu), \\
& \left.d n / d r=4.1 \times 10^{4} \mathrm{~cm}^{-3} \mu^{-1}(0.03 \leq r<0.1 \mu) .\right\}
\end{aligned}
$$

This law is adopted from the results for terrestrial dusty atmosphere obtained over northwest India (mostly desert) (e.g. Peterson, 1968; Peterson and Weinman, 1969). In the earth atmosphere, this is often used to calculate the optical properties of quartz dust particles.

Another unknown factor is the vertical profile of dust density. We assumed three cases of dust density decreasing with height: The first case is of very high concentration up to $800 \times 10^{-6} \mathrm{~g} \cdot \mathrm{m}^{-3}$ near the ground (Fig. 3(a)). This dust profile is similar to that observed over the terrestrial desert (Peterson, 1968). The second is of lower dust density up to $80 \times 10^{-6} \mathrm{~g} \cdot \mathrm{m}^{-3}$ (Fig. 3(b)), and the third is of very low concentration up to $8 \times 10^{-6}$ $\mathrm{g} \cdot \mathrm{m}^{-3}$ (Fig. 3(c)).

An estimate of the magnitude of the amount of dust would be made by comparison these assumptions with the Mars observations. By comparison of surface visibility at the Martian dust storm event with that of out-of-storm case, Leovy et al. (1972) reported that at the dust storm event optical depth of the dust becomes about two and decreases down to approximately 0.1 by improvement of visibility at post dust storm. Parkinson and Hunten (1972) also measured an optical depth of unity for 1 micron radiation at about $10 \mathrm{~km}$, at the dust storm event. It may be said that the dust concentration in our first and probably second cases would correspond to dust storm event, and the third to post-storm case.

We used the same numerical iterative method as Sargent and Beckman (1973), to obtain the solution of eq. (4), $I_{\nu}(z, \eta)$. Phase function depends upon scattering angles. In order to solve eq. (4) exactly, we must divide the whole scattering angles into a large number of directions. But, in the actual computation, it is difficult to do so, because a lot of time will be spent to obtain the results. So, following to Sargent and Beckman (1973), we divide scattering phase function into three parts, i.e., forward-scattering peak, diffusely forward-scattering and diffusely backward-scattering. Thus eq. (4) comes to a set of the simultaneous ordinary differential equations. The numerical integration is based upon Hamming method for the solution of ordinary differential equations.

As the extension of our atmosphere, we assumed that the top of dust atmosphere is 10 $\mathrm{km}$ in height. Upper boundary condition is

$$
I_{\nu} \downarrow(z,-\eta)=0 \quad \text { at } z=10 \mathrm{~km},
$$

and lower boundary condition is

$$
I_{v} \uparrow(o, \eta)=B_{v}[T(0)] \text { at } z=0 \mathrm{~km} \text { (ground). }
$$

In regions of very strong gas absorption a numerical integration without dust is used. For the $\mathrm{CO}_{2}-15 \mu$ band, we calculate the cooling rate of air with the use of "strong line approximation". (Plass, 1960; Prabhakara and Hogan, 1965).

The IR region used in the present calculation ranges from $280 \mathrm{~cm}^{-1}$ to $3000 \mathrm{~cm}^{-1}$, and is divided into 15 intervals.

\section{Computed results}

As a check on the accuracy of the numerical integration, we calculated upward flux and net infrared flux resulting from quartz aerosols for the case of the terrestrial atmosphere, and compared our results with those of Peterson (1968) in Fig. 1. Peterson has calculated these values by the use of the two-stream approximation in solving equation of radiative transfer. Particle size distribution assumed in the model is the same as that expressed by eq. (9), and the vertical profile of dust density corresponds to the case presented in Fig. 3(a). The results shown in Fig. 1 allow considerable confidence to be placed in our numerical model.

In Fig. 2, atmospheric transmissivity is shown for quartz dust and for $\mathrm{CO}_{2}$ gas, using dust profile data between the ground and $10 \mathrm{~km}$ for a heavy dust storm case. One can see that the dust extinction should not be overlooked in the IR region. In the Martian atmosphere, it is expected 
that dust would play a more important role in IR transfer problem than in the terrestrial case, because the Martian atmosphere is thin and highly transparent to longwave radiation.

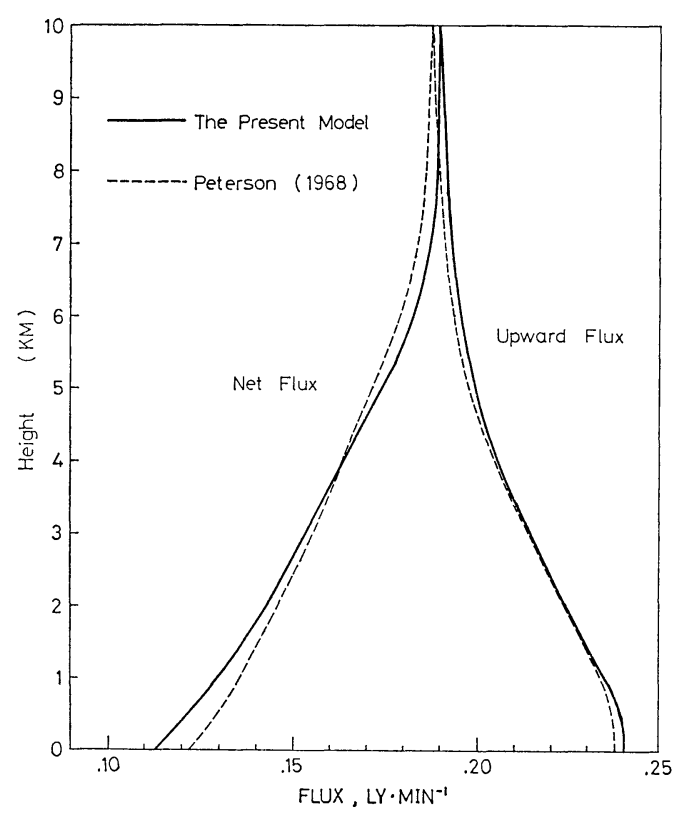

Fig. 1. Comparison of upward flux and net flux calculated by our model with the results of Peterson's numerical evaluation.
Estimated radiative cooling rates, for the cases of high dust concentration, are shown in Fig. 3(a) and (b). Our results indicate that cooling rate is a few tens degrees or more per day at lower levels of dust layer.

This is an important result. Gierasch and Goody treated only of the atmospheric heating by direct absorption of visual light due to dust. But, the thermal structure in the dusty atmosphere seems to be determined more complicatedly than Gierasch and Goody argued, because the IR radiative cooling rate due to dust is very large, especially in the lower layers, as described above.

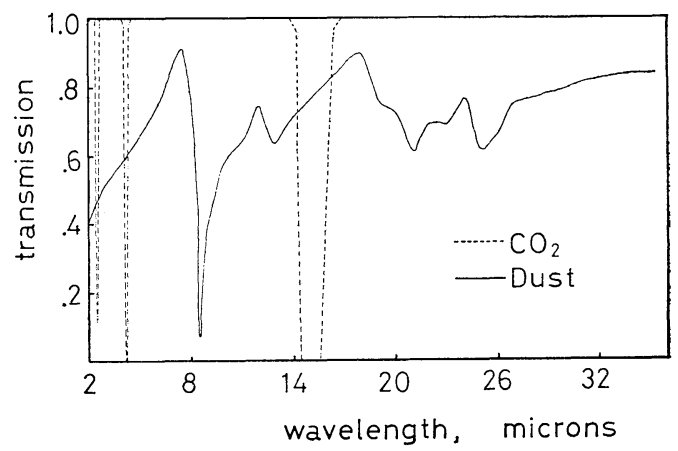

Fig. 2. Spectral transmissivity of carbon dioxide and quartz dust between the ground and dust top for the case of a heavy dusty atmosphere.

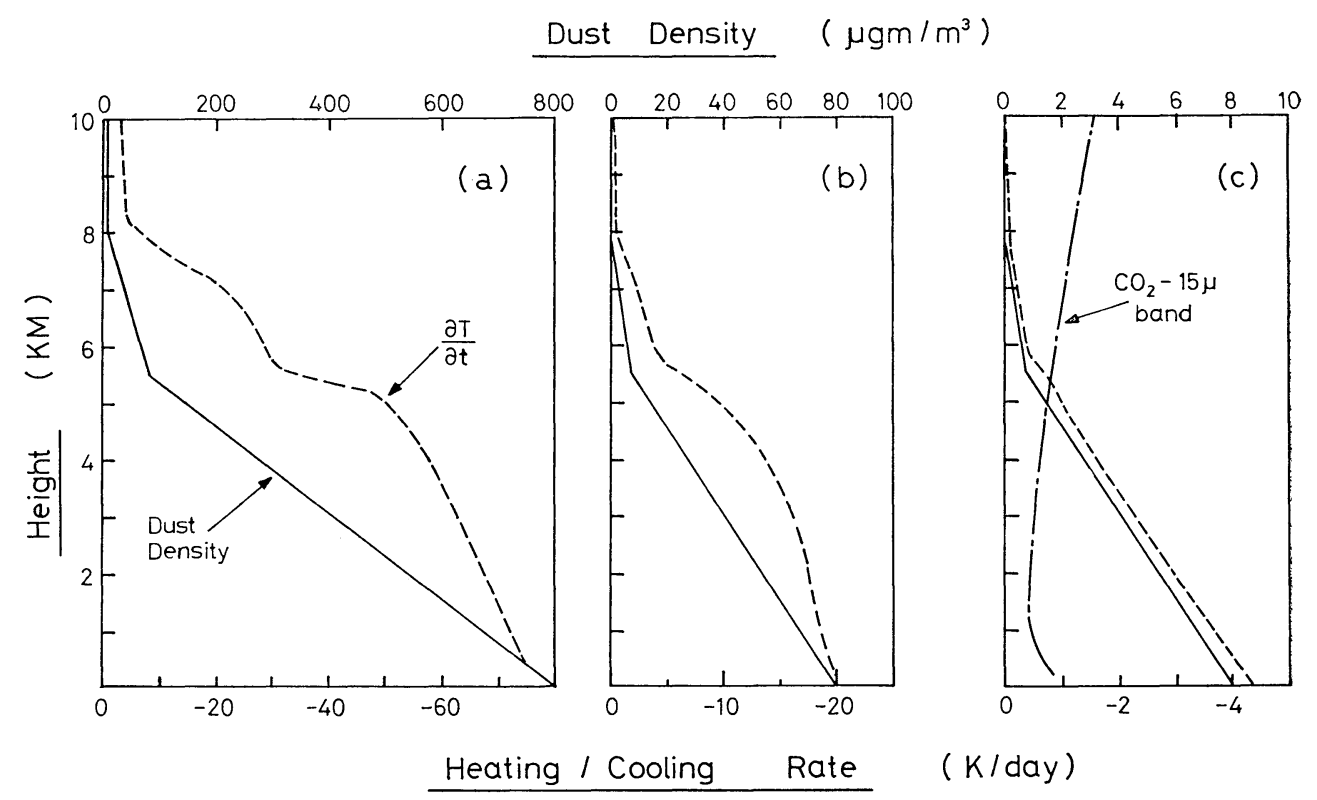

Fig. 3. Vertical dust density profiles assumed in this work (solid lines) and the infrared radiative cooling rate due to dust (dashed lines). Cooling rate due to $\mathrm{CO}_{2}-15 \mu$ band is also shown in Fig. 3(c). 
When we discuss the problem on thermal structure of the Martian atmosphere, it is absolutely necessary that we should consider the effect of dust on IR radiation transfer. In fact, as described in Section 1, a large nighttime cooling probably due to dust of $12 \mathrm{~K} /$ day on an average in the atmospheric column is reported from analyses of Mariner 9 observations (Pirraglia and Conrath, 1974). This is in good agreement with our results of dusty cases.

Now, Fig. 3(c) shows radiative cooling rate by dust for the case of out-of-storm events. The rate is expected to be several degrees per day in the lower layers. Since cooling rate due to $\mathrm{CO}_{2}$ is a few degrees per day (Fig. 3(c)), this fact would indicate that even at out-of-storm events, suspended dust considerably affects the transfer of radiation through the atmosphere.

\section{Coclusions}

Our results indicate that the IR radiative cooling due to dust should not be overlooked in radiative transfer problem in the Martian atmosphere as well as heating due to direct absorption of solar radiation, and especially that at the dust storm event, thermal structure of the atmosphere would be determined by dust alone.

When the Martian dust storm develops rapidly, a large amount of dust suspended in the atmosphere would absorb a significant amount of the incident solar radiation, and therefore, the upper portion of the dust layer would be heated up considerably, and the lower boundary region in such very opaque dust atmosphere would receive less radiation. Moreover, as pointed out in the previous section, in such lower portion of dust layer, cooling due to the IR radiation of dust becomes one of the most predominant term in heat budget. Therefore it may safely be said that at the heavy dust storm case the upper portion within dust layer is heated up by solar radiation, and on the other hand, the lower level is cooled. This would reduce the temperature gradient with height and stabilize the temperature distribution. This stabilization of atmosphere due to dust is in qualitative agreement with many observations of Mariner 9 during the heavy dust storm event (Kliore et al., 1972; Hanel et al., 1972; Masursky et al., 1972).

Our calculation is based upon several unknown parameters, i.e., particle size distribution, dust density profile with height and dust composition.
Without detailed criticism for these parameters, we can not step out into further rigorous discussion on real atmosphere, although our results would not differ from the exact ones so much.

\section{Acknowledgement}

The author wishes to thank Dr. Sumisaburo Saito of the Kwasan Observatory of Kyoto University for careful reading of the manuscript.

\section{References}

Gierasch, P., and R. M. Goody, 1968: A study of the thermal and dynamical structure of the Martian lower atmosphere. Planet. Space Sci., 16, 615-646. -, and 1972: The effect of dust on the temperature of the Martian atmosphere. J. Atmos. Sci., 29, 400-402.

$\longrightarrow$, and 1973: A model of a Martian great dust storm. J. Atmos. Sci., 30, 169179.

Hanel, R., B. Conrath, W. Hovis, V. Kunde, P. Lowman, W. Maguire, J. Pearl, J. Pirraglia, C. Prabhakara, B. Schlachman, G. Levin, P. Straat, and T. Burke, 1972: Investigation of the Martian environment by infrared spectroscopy on Mariner 9. Icarus, 17, 423-442.

Kliore, A. J., D. L.Cain, G. Fjeldbo, B. L. Seidel, M. J. Sykes, and S. I. Rasool, 1972: The atmosphere of Mars from Mariner 9 radio occultation measurements. Icarus, 17, 484-516.

Leovy, C. B., G. A. Briggs, A. T. Young, B. A. Smith, J. B. Pollack, E. N. Shipley, and R. L. Wildey, 1972: The Martian atmosphere: Mariner 9 television experiment progress report. Icarus, 17, 373-393.

Masursky, H., R. M. Batson, L. F. McCauley, L. A. Soderblom, R. L. Wildey, M. H. Carr, D. J. Milton, D. E. Wilhelms, B. A. Smith, T. B. Kirby, J. C. Robinson, C. B.Leovy, G. A. Briggs, T. C. Duxbury, C. H.Action, Jr., A. T. Young, B. C. Murray, J. A. Cutts, R. P. Sharp, S. A. Smith, R. B. Leighton, C. Sagan, J. Veverka, M. Noland, J. Lederberg, E. Levinthal, J. B. Pollack, J. T. Moore, Jr., W. K. Hartmann, E. N. Shipley, G. DeVaucouleurs, and M. E. Davies, 1972: Mariner 9 television reconnaisance of Mars and its satellites: preliminary results. Science, 175, 294-304.

Moriyama, S., 1972: Numerical experiment of radiativeconvective equilibrium of the Martian atmosphere. J. Meteor. Soc. Japan, 50, 181-193.

Ohring, G., and J. Mariano, 1968: Seasonal and latitudinal variations of the average surface temperature and vertical temperature profile on Mars. J. Atmos. Sci., 25, 673-681.

Parkinson, T. D., and D. M. Hunten, 1972: Martian dust storm: Its depth on 25 November 1971. 
Science, 175, 323.

Peterson, J. T., 1968: Measurement of atmospheric aerosols and infrared radiation over Northwest India and their relationship. ONR Tech. Rept. No. 38, Dept. of Meteorology, University of Wisconsin. 165 pp.

and J. A. Weinman, 1969: Optical properties of quartz dust particles at infrared wavelengths. J. Geophys. Res., 74, 6947-6952.

Pirraglia, J. A., and B. J. Conrath, 1974: Martian tidal pressure and wind fields obtained from the Mariner 9 infrared spectroscopy experiment. J. Atmos. Sci., 31, 318-329.
Plass, G. N., 1960: Useful representations for measurements of spectral band absorption. J. Opt. Soc. Amer., 50, 868-875.

Prabhakara, C., and J. S. Hogan, Jr., 1965: Ozone and carbon dioxide heating in the Martian atmosphere. J. Atmos. Sci., 22, 97-109.

Sargent, S. L., and W. A. Beckman, 1973: A numerical model of thermal radiation in a dusty atmosphere. J. Atmos. Sci., 30, 88-94.

Spitzer, W. G., and D. A. Kleinman, 1961: Infrared lattice bands of quartz. Phys. Rev., 121, 13241335 .

\section{放射伝達に及ぼす火星大気中のダストの効果（その 1）}

一一赤外放射冷却について—

森山茂

日本大学理・工系習志野校舎, 物理教室

赤外領域で, 吸収, 放射, 散乱の効果を考慮して, ダストを含む火星大気について, その放射伝達の方程式を数植 的に解いた，ダストの主成分としては，石英が仮定されている．ダストの濃度に関しては，三つのケースで計算がな された，一番目は非常にダストの多い場合，二番目はやや多い場合，三番目は非常にダスト濃度が小さく，大気のか なり倩れ上っている場合である，遂次近似法によって得られた解から，火星大気中のダストによる放射冷却率を高度 の関数として計算した.

それによると，火星では，ダストによる赤外放射冷却率は，下層で看過しえない事を示している，特に，砂嵐の起 っている時には, 赤外領域での冷却は, 太陽光の直接吸収による加熱同様, 大気の熱的な問題にとって, 非常に重要 であろう，そして，この時，火星大気の熱的な構造はダストのみによって決定されているように思われる，更に， ま た，晴れている時でも，ダストによる赤外放射冷却は， $\mathrm{CO}_{2}$ によるそれと同程度に効いていることを示している。 